\title{
THE CLASSIFICATION OF TOTAL QUALITY MANAGEMENT IMPLEMENTATION IN GUEST HOUSES
}

\author{
Muhammad Fauzan Robbani \\ Management Department, Faculty of Economics and Business \\ Universitas Muhammadiyah Malang \\ E-mail: fauzanrobbani20@gmail.com
}

\begin{abstract}
This study aims to find out and analyze the classification of guest houses based on TQM implementation in Klojen Sub-district, Malang. The analytical method used was cluster analysis with 18 guest houses as the research objects and 22 statements about TQM in the questionnaire. The results showed that there were two groups of guest houses formed based on the TQM implementation. The first group was the guest house group which had theoritical TQM implementation and a vision. This group was also oriented to quality with good Human Resources who were given a freedom to be involved in it, and they constantly made continuous improvements focusing on the consumers' wants and needs. Meanwhile, group 2 was the guest house group with TQM implementation which was built with strong teamwork and long-term commitment to implement it. For both groups, it is important to maintain the strong TQM variables and to improve the TQM variables that have not been implemented.
\end{abstract}

Keywords : total quality management, guest house, service

\section{INTRODUCTION}

The rapid development of technology and science create a lot of changes in human life. This development was also perceived in the economic sector. The increasingly competitive competition environment causes the old players and new players in the business world perform efforts in improving the quality of their products or services.

Companies engaged in the service sector need to be able to survive since the competition is increasingly widespread, not only the local competition but also the global competition. In order to survive in this intense competitive situation, the companies must be able to provide qualified products or services, at affordable prices, and more efficient and better services than their competitors. One of the things that can be carried out is by performing continuous innovations on the quality of the products or services and its people. This underlies the idea of the need for an integrated quality management system such as Total Quality Management (TQM).

Total Quality Management, abbreviated as TQM, is a quality control tool that can be implemented in manufacturing or service companies. Baraba (2016) states that 
many companies have implemented TQM, however, few of them have failed. TQM can be successfully implemented if there is a commitment from all levels of the organization to jointly support its implementation.

Malang, as a city whose reputation is famous for its education, attracts numerous students from outside the city. The comers cause the money circulation in the city even higher, making the growth of the city even better. The business world grows because of this circulation; one of the many businesses that build in this city is the lodging business or commonly called as the Guest House. Guest House is a business engaged in services.

Service businesses need to pay special attention to the quality of their services because they are directly involved with the customers. A Guest House that does not pay attention to the quality of its services will make the consumers reluctant to recommend the Guest House to other people. Consequently, this decreases the company's income. Furthermore, the customers who are not satisfied with the services of the company will give poor judgements or complaints submitted through social media.

Some complaints the customers can be read on a review application, namely TripAdvisor. According to Soegiyono (2015), the reader's mind stated on newspapers, magazines, and social media that complains about the quality of products or services of a company can be seen as a problem. This is because it is reported through the media so that many people become aware of the quality of the products and services. Moreover, the complaints submitted by the consumers can be a benchmark of the company quality, especially in the service business. Accordingly, it is important to make breakthroughs to improve the quality of its services so that it can provide the best for the consumers. One of the quality control methods that can be implemented by companies engaged in services is Total Quality Management (TQM).

Preliminary research related to the constraints in implementing TQM has been conducted by interviewing six managers of guest houses located in Klojen sub-district. The obstacles faced by the guest houses that implement TQM include no education and training about TQM has been conducted previously, top managers (owners) have no experience in hospitality, problems with the third parties who are late in making payments, some misunderstandings between company members in carrying out their duties, no career paths, lack of facilities, and problems with employees who do not understand the importance of quality.

The proper implementation of Total Quality Management (TQM) will improve the company performance since TQM has an effect on company performance (Al-Faritsy $\&$ Suseno, 2014). In order to succeed the implementation of TQM in Guest Houses, a research is needed to explore the extent of to which TQM has been implemented and the things that need to be improved to overcome the difficulties associated with the TQM implementation, especially for Guest house. 


\section{LITERATURE REVIEW}

In the business world, both manufacturing and service, quality is always an important thing to consider because consumers will see a product or service from its quality. The definition of quality according to Heizer and Render (2015) is all features and characteristics of a product or service that is able to satisfy the visible or vague needs. Another opinion comes from Goetsch and Davis (in Tjiptono and Diana, 2001) who claim that quality is a dynamic condition related to products, services, people, processes, and environments that meet or exceed the expectations. From the above definitions, it can be concluded that quality is the overall features of a product or service that if it is good, it can satisfy and meet customer expectations. Therefore, it is important for the company to maintain and improve its quality.

Quality control has many methods in it, one of which is Total Quality Management (TQM). TQM can be used in manufacturing or service companies. The definition of TQM should be understood from two perspectives, namely what is TQM, and how to be able to achieve it. Total Quality Management is an approach in running a business that tries to maximize the competitiveness of an organization through continuous improvement of products, services, people, processes, and the environment (Tjiptono \& Diana, 2001). Moreover, according to Heizer and Render (2013), TQM refers to the emphasis on quality covering the organization as a whole starting from the suppliers.
The second point of view, in addition to the definition of TQM, is how to achieve it. In other words, what factors that make TQM successful. There are several factors which can make TQM be a success. The main elements of TQM are factors that can make TQM successful. There are numerous factors that can make TQM succeeded depending on the theory used. According to Goetsch and Davis (in Tjiptono and Diana, 2001), TQM has ten main elements in how to achieve it.

The first is customer focus, namely the implementation of TQM focusing on customer wants and needs. Various customer desires and needs as much as possible become input to create or develop the products and services that can satisfy the customers. The satisfied customers tend to be loyal to the products or services that can meet their desires and needs. As a result, the company needs to focus on the customer needs and desires so that the company's goal to get loyal customers and increase its profits will be achieved if TQM is implemented correctly.

Second, an obsession toward the quality, that is, the quality of a company's product or service that is assessed by the customers. The customers expect that the company has an obsession to meet the customers' expectations or even exceed those expectations. This means that all employees try to carry out every responsibility and if possible, more than necessary. If this is performed, the customers' expectations for the quality of the 
products or services of a company can be met.

A scientific approach is needed for companies implementing TQM. Starting from designing work to decision making as well as the implementation should be well designed. This makes the companies easier to revise errors arised by referring to the plans that have been made and determined at the beginning. In other words, the scientific approach is the form of compiling data that is used to compose benchmarks, monitor achievements, and carry out improvements.

The fourth is a long-term commitment. TQM is a method requiring continuous refinement and improvement in its implementation. Therefore, in order to be able to implement TQM successfully, it requires a long-term commitment from all members of the organization. The long-term commitment in implementing TQM will form a good new culture for continuous improvement in the quality of the company.

The fifth, teamwork. An organization that implements TQM requires harmonious relationships among its employees, suppliers, government institutions, and the surrounding community. This teamwork is needed to make the implementation of TQM successful. Furthermore, teamwork can reduce the level of futile conflict that can cause the decline in productivity of the members of the organization and the elements involved in it.

Another element is continuous improvement. Every good product or service is produced from a good system. In order to maintain the quality, system adjustment toward the environment such as adjusting the system to the advancement of technology so that the latest systems have adopted technology and digitalization is needed.

The seventh element is education and training. In organizations implementing TQM, education and training are absolutely necessary. This is because TQM is a sustainable method with continuous improvement. The improvements and innovations require new knowledge and new capabilities to make the implementation more optimal. Accordingly, the existing human resources need to be given education and training so that their knowledge continues to grow to contribute more to the company.

The next is a controlled freedom. Freedom here means that in implementing TQM, the company gives freedom to the employees to be involved in decision making. This can increase employees' sense of ownership and responsibility towards the company. Nevertheless, the freedom arising from the involvement and empowerment of employees should be the result of well-planned and implemented controls.

The ninth element is the unity of purposes. The implementation of TQM can be successful if all members of the organization have one common goal and vision. Therefore, each policy can be directed at the same goal. However, this unity of purpose does not apply in determining employees' wages and working conditions. This is because the matters relating to the 
company's ability to provide something in the form of money need considerations so that the company does not spend excessive expenditure.

The last element is employee involvement and empowerment. The implementation of TQM needs to involve and empower employees in terms of decision making and problem solving. This is because it can foster the employees' sense of ownership and responsibility toward the decisions made. Accordingly, these decisions will be carried out seriously. In addition, the employees' involvement can enrich the insights and views of a problem and the decisions taken since more parties are involved in the process.

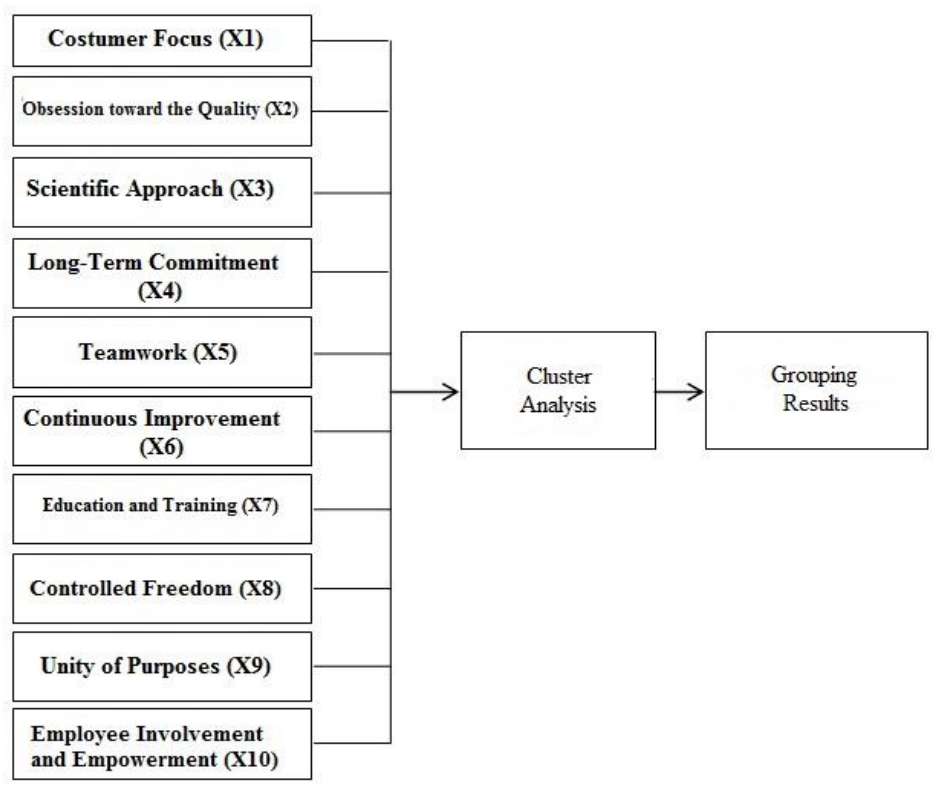

Figure 1. Framework

Source : Al-Ababneh dan Lockwood (2012)

\section{METHOD}

The research was conducted directly on the objects of the research, namely the Guest Houses in Klojen Sub-district, Malang. The objects of this research were the Guest House managers and supervisors located in Klojen Sub-district, Malang. Furthermore, this research was descriptive quantitative research. According to the method, this research was a descriptive research, a research which includes collecting data to answer questions about the final status of the research subjects (Kuncoro,
2013). This research employed ten Total Quality Management variables that assisted in determining the results of research in the form of the implementation of Total Quality Management in Guest Houses in Klojen Sub-district, Malang. The procedures of the analysis tools were cluster analysis, starting from determining the research problem, the similarity measurement method, the cluster procedure used, the number of clusters formed, and interpreting the results of cluster analysis (Malhotra, 2005). 


\section{RESULT AND DISCUSSIONS}

The problems faced were complaints from consumers about Guest House services posted on social media and these complaints were accessible to be read by many people. Accordingly, a comprehensive quality control or Total Quality Management was needed. The preliminary research was conducted on six Guest House managers regarding the obstacles in implementing TQM at the Guest Houses. The obstacles included no education and training about TQM had been conducted previously, top managers (owners) had no experience in hospitality, problems with the third parties who were late in making payments, misunderstandings between company members in carrying out their duties, no career paths, and lack of facilities. The next stage of data analysis was to choose the cluster procedure used. According to Malhotra (2005), the hierarchical and non-hierarchical cluster analysis method can be used together. As a result, this research used the hierarchical cluster procedure to determine the number of clusters formed from the dendogram, then the analysis continued with the nonhierarchical clusters analysis.

The method used in this hierarchical cluster was agglomerative, namely grouping objects based on the calculation of the closest distance among these objects by using the average linkage method, that was the method of average relationship amongst all pair of objects where one member of the pair came from each group carried out with the SPSS 22.0 for windows program. The results were shown as in Table 1 below:

Table 1. Agglomeration Schedule Result

\begin{tabular}{|c|c|c|c|c|c|c|}
\hline \multirow{2}{*}{ Stage } & \multicolumn{2}{|c|}{ Cluster Combined } & \multirow{2}{*}{ Coefficient } & \multicolumn{2}{|c|}{$\begin{array}{l}\text { Stage Cluster First } \\
\text { Appears }\end{array}$} & \multirow{2}{*}{$\begin{array}{l}\text { Next } \\
\text { Stage }\end{array}$} \\
\hline & Cluster 1 & Cluster 2 & & Cluster 1 & Cluster 2 & \\
\hline 1 & 4 & 9 & 0.271 & 0 & 0 & 6 \\
\hline 2 & 7 & 12 & 1.111 & 0 & 0 & 11 \\
\hline 3 & 11 & 14 & 1.250 & 0 & 0 & 6 \\
\hline 4 & 8 & 17 & 1.721 & 0 & 0 & 9 \\
\hline 5 & 2 & 16 & 2.034 & 0 & 0 & 10 \\
\hline 6 & 4 & 11 & 2.348 & 1 & 3 & 14 \\
\hline 7 & 1 & 5 & 2.843 & 0 & 0 & 9 \\
\hline 8 & 15 & 18 & 3.547 & 0 & 0 & 13 \\
\hline 9 & 1 & 8 & 1.654 & 7 & 4 & 13 \\
\hline 10 & 2 & 10 & 3.718 & 5 & 0 & 12 \\
\hline 11 & 7 & 13 & 4.111 & 2 & 0 & 12 \\
\hline 12 & 2 & 7 & 5.312 & 10 & 11 & 15 \\
\hline 13 & 1 & 15 & 5.585 & 9 & 8 & 14 \\
\hline 14 & 1 & 4 & 6.346 & 13 & 6 & 16 \\
\hline 15 & 2 & 6 & 7.074 & 12 & 0 & 16 \\
\hline 16 & 1 & 2 & 9.064 & 14 & 15 & 17 \\
\hline 17 & 1 & 3 & 12.953 & 16 & 0 & 0 \\
\hline
\end{tabular}

According to Malholtra (2005), in order to determine the number of clusters, the researcher can use theory, concepts, or practical considerations that can determine the number of clusters. In the hierarchical clusters, the distance where clusters were combined could be used as the criteria which were described in Figure 2: 

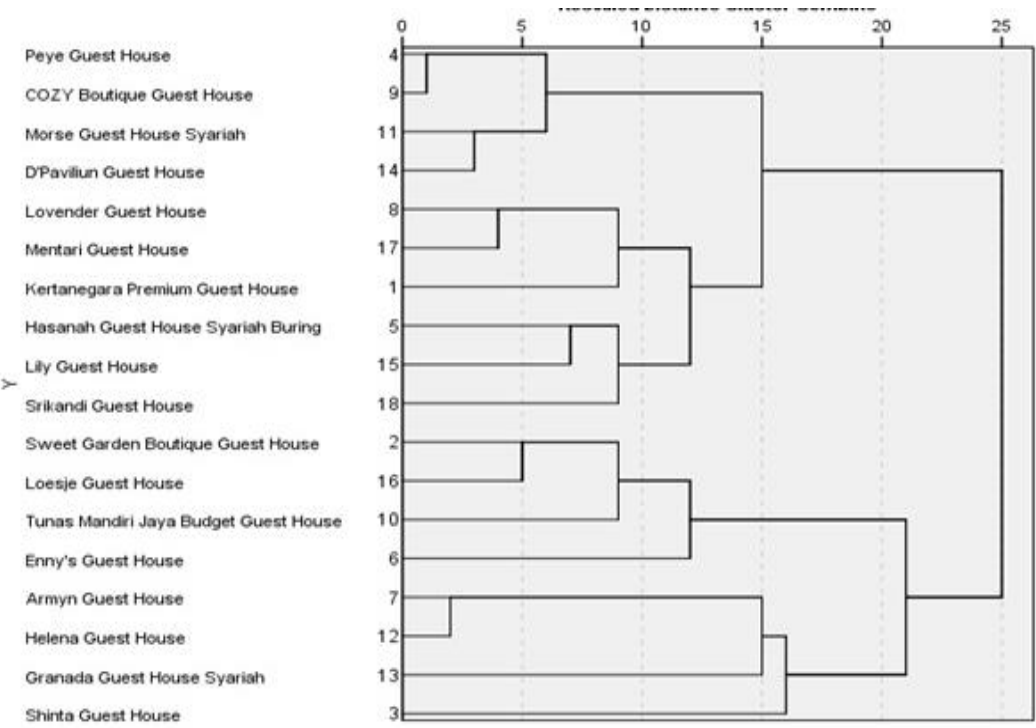

Figure 2. Dendogram

Based on Figure 2, that was the dendogram results from the hierarchical cluster analysis, the clusters which could be formed optimally were two clusters. The optimal cluster was indicated by not only one object in one cluster. The details of the clusters and their members were in Table 2:

Table 2. Cluster Categorization

\begin{tabular}{ll}
\hline Cluster & Member \\
\hline \multirow{2}{*}{1} & Kertanegara Premium Guest House \\
& Peye Guest House \\
& Hasanah Guest House Syariah Buring \\
& Lovender Guest House \\
& COZY Boutique Guest House \\
& Morse Guest House \\
& Helena Guest House \\
& D'Paviliun Guest House \\
& Mentari Guest House \\
& Srikandi Guest House \\
& Sweet Garden Boutique Guest House \\
& Shinta Guest House \\
& Enny's Guest House \\
& Armyn Guest House \\
& Tunas Mandiri Jaya Guest House \\
& Granada Guest House \\
& Lily Guest House \\
& Loesje Guest House \\
\hline
\end{tabular}

The next stage of cluster analysis was non-hierarchical cluster analysis or k-mean cluster that used two clusters formed employing the hierarchical cluster analysis as the basis. By using the non-hierarchical cluster analysis, the centroid cluster results that have varied scores were found. These scores showed the dominant value of each cluster, namely the higher the score of a variable, the more dominant it was. In addition, the higher score also reflected the characteristics of the cluster more. This was shown in Table 3 as follows:

Table 3. Cluster Centroid

\begin{tabular}{lcc}
\hline Final Cluster Centers & \multicolumn{2}{l}{ Cluster } \\
\cline { 2 - 3 } Category & 1 & 2 \\
\hline Costumer Focus & 4.45 & 3.97 \\
Obsession toward Quality & 4.60 & 3.50 \\
Scientific Approach & 4.90 & 4.00 \\
Long-term Commitment & 4.40 & 4.50 \\
Teamwork & 4.60 & 4.75 \\
Continous Improvement & 4.50 & 3.75 \\
Education and Training & 4.28 & 3.53 \\
Controlled Freedom & 4.50 & 3.88 \\
Unity of Purposes & 4.30 & 4.13 \\
Employee Empowerment & 4.50 & 3.71 \\
\hline
\end{tabular}


As shown in Table 3, the cluster 1 almost dominated the entire variable, namely eight variables with the highest values. This showed that in cluster 1, the guest houses had strong customer focus, obsession with quality, scientific approach, teamwork, continuous improvement, education and training, controlled freedom, unity of purpose, and involvement and empowerment of employees. Meanwhile, the cluster 2 showed strong long-term commitment and teamwork variable while the other variables were not stronger than the cluster 1 .

Based on the previous explanation, it could be said that the cluster 1 was a cluster consisting of guest houses with Total Quality Management implementation more than cluster 2 and cluster 2 was a cluster with Total Quality Management implementation lesser than cluster 1. Based on Table 2, the members of cluster 1 were ten guest houses namely Kertanegara Premium, Peye, Hasanah, Lovender, Cozy Boutique Guest House, Morse,
Helena, D'Paviliun, Mentari, dan Srikandi,. The characteristics of cluster 1 were having a high customer focus, a strong obsession with quality, scientific approach, continuous improvement, education and training, controlled freedom, unity of purpose, and involvement and empowering of employees. Meanwhile, the members of cluster 2 were like Sweet garden, Shinta, Enny's, Armyn,, Tunas Mandiri Jaya, Granada, Lily, Loesjie, has strong long-term commitment and teamwork characteristics.

Furthermore, the next step is to observe if there were variables that caused a difference in this clustering. According to Sitepu et al (2011), to know whether the variables that have formed the cluster were distinguishing variables in clustering, this can be seen in Tabel 4 as follows. In addition, the level of significance needed to be considered, if the significance was above 0.05 then the variable did not make a significant difference for each cluster.

Table 4. ANOVA Analysis Result

\begin{tabular}{lcccccc}
\hline \multirow{2}{*}{ Category } & \multicolumn{2}{c}{ Cluster } & \multicolumn{2}{c}{ Error } & \multirow{2}{*}{ F } & Sig, \\
\cline { 2 - 5 } & $\begin{array}{c}\text { Mean } \\
\text { Square }\end{array}$ & Df & $\begin{array}{c}\text { Mean } \\
\text { Square }\end{array}$ & Df & & \\
\hline Costumer Focus & 1.029 & 1 & 0.150 & 16 & 6.849 & 0.019 \\
Obsession toward Quality & 5,378 & 1 & 0.400 & 16 & 13.444 & 0.002 \\
Scientific Approach & 3,600 & 1 & 0.181 & 16 & 19.862 & 0.000 \\
Long-term Commitment & 0,044 & 1 & 0.275 & 16 & 0.162 & 0.693 \\
Teamwork & 0,100 & 1 & 0.244 & 16 & 0.410 & 0.531 \\
Continous Improvement & 2,500 & 1 & 0.375 & 16 & 6.667 & 0.020 \\
Education and Training & 2,533 & 1 & 0.261 & 16 & 9.718 & 0.007 \\
Controlled Freedom & 1,736 & 1 & 0.336 & 16 & 5.168 & 0.37 \\
Unity of Purposes & 0,136 & 1 & 0.436 & 16 & 0.312 & 0.584 \\
Employee Empowerment & 2,785 & 1 & 0.218 & 16 & 12.784 & 0.003 \\
\hline
\end{tabular}

Based on Table 4, it could be seen that there were three variables that did not have a significant difference for each cluster. The variables were long-term commitment variable with a 
significance of 0.693 , teamwork variable with a significance of 0.531 , and unity of purpose variable with a significance of 0.584 . Therefore, in accordance with the results of the data analysis above, it could be concluded that TQM implementation in the Guest Houses in the Subdistrict of Klojen Malang could be classified into two groups. Group 1 was the Guest House group which had theoritical TQM implementation and a vision. This group was also oriented to quality with good Human Resources who were given a freedom to be involved in it, and they constantly made continuous improvements focusing on the consumers' wants and needs. Meanwhile, group 2 was the Guest House group with TQM implementation which was built with strong teamwork and long-term commitment to implement it.

From the results of this grouping, it could be discovered that there were two TQM variables that had not been implemented or had not been maximally implemented in group 1, namely long-term commitment and teamwork variable. Consequently, it was expected that the Guest Houses in group 1 could increase the implementation of TQM by focusing on long-term commitment and teamwork variable.

On the other hand, there were eight TQM variables that had not been implemented or had not been maximally implemented in group 2, namely variable of focus on customers, obsession with quality, scientific approach, continuous improvement, education and training, controlled freedom, unity of purpose, and involvement and empowerment of employees. Accordingly, the Guest Houses in group 2 were expected to escalate the implementation of TQM by focusing on those eight variables.

\section{CONCLUSION}

The classification of guest houses based on their implementation of Total Quality Management produces two groups. The first is group 1, the guest houses which has theoritical TQM implementation and a vision. This group is also quality-oriented with good Human Resources who are given a freedom to be involved in it, and they constantly perform continuous improvements focusing on the wants and needs of the consumers. Meanwhile, the second group is group 2, that is the guest house group with TQM implementation which was founded with strong teamwork and long-term commitment to implement it.

Group 1 with high TQM implementation has high customer focus, quality obsession, scientific approach, continuous improvement, education and training, controlled freedom, unity of purpose, and involvement and empowerment of the employees. In the meantime, group 2 with lesser TQM implementation has high long-term commitment and teamwork.

The cluster analysis of TQM implementation at these guest houses can provide an overview of the implementation of TQM in guest houses, hence, it can be discovered which TQM variables that need to be improved and maintained in order to provide better and qualified services. Accordingly, they will not receive 
many complaints from the consumers regarding the quality of services. Moreover, for group 1, it is necessary to improve the variable of long-term commitment and teamwork, while group 2 needs to escalate the variable

\section{REFERENCES}

Al-Ababneh, M. \& Lockwood, A. (2012). Implementing Total Quality Management In The Hotel Industry. Journal of Tourism \& Hotel Management

Al-Ababneh, M. (2014). Classifying Jordanian Hotels Based on Their Implementations. Journal of Administrative Sciences Vol. 41 No.2

Al-Faritsy, A.Z \& Suseno (2014). Penerapan Total Quality Management Dalam Meningkatkan Kinerja Perusahaan UMKM. Jurnal Studi Manajemen, Vol. 8, No. 2, Oktober 2014

Alhudri, Said dan Heriyanto, Meyzi. (2015). Pengaruh Penerapan Total Quality Management (TQM) Terhadap Kinerja Karyawan Pada PT. PLN (Persero) Ranting Bangkinang. Jom FISIP Vol. 2 No. 2

Al-Sabi, Samer M. dkk. (2017). The Impact of Total Quality Management Implementation On Employees' Service Recovery Performance in FiveStar Hotels in Jordan. European Journal of Business and Management Vol. 9 No. 11

Azlina, Nur Dkk. (2013). Pengaruh Total Quality Management Terhadap Kinerja Financial. Vol. 1 No. 2

Arikunto, Suharsimi. (2010). Prosedur Penelitian : Suatu of focus on customers, obsession with quality, scientific approach, continuous improvement, education and training, controlled freedom, unity of purpose, and involvement and empowerment of the employees.

Pendekatan Praktik. Jakarta : Rineka Cipta.

Baraba, R. (2016). Pengelolaan TQM Pada Bisnis Perhotelan. E-Journal Universitas Muhammadiyah Purworejo

Febrianti dkk. (2014). Analisis Pengaruh Budaya Kualitas Perusahaan Terhadap Keberhasilan Implementasi TQM Menggunakan Metode SEM

Heizer, Jay \& Render, Barry. (2013). Manajemen Operasi. Jakarta : Penerbit Salemba Empat.

Kuncoro, Mudrajad. (2013). Metode Riset Untuk Bisnis dan Ekonomi. Jakarta : Penerbit Erlangga

Lupiyoadi, Rambat \& Ikhsan, Ridho Bramulya. (2015). Praktikum Metode Riset Bisnis. Jakarta : Penerbit Salemba Empat

Malhotra, K. Naresh. (2005). Marketing Research: An Applied Orientatation. Prentice Hall International, Inc.

Panuwatwanich, Kriengsak dan Nguyen, Thanh Tung. (2017). Influence of Organisational Culture On Total Quality Management Implementation and Firm Performance: Evidence From The Vietnamnese Construction Industry. Management and Production Engineering Review Vol. 8 No. 1 
Ratnaningrum \& Nasron, Muh. (2014). Prakik TQM, Persepsi Kualitas Layanan dan Kepuasan Pengunjung. BENEFIT Jurnal Manajemen dan Bisnis Vol. 17 No. 1

Sitepu, Robinson dkk. (2011). Analisis Cluster Terhadap Tingkat Pencemaran Udara pada Sektor Industri di Sumatera Selatan. Jurnal Penelitian Sains Vol. 14 Nomor 3 (A)

Soegiyono. (2015). Metode Penelitian Kuantitatif,
Kualitatif, dan $R \& D$. Bandung: Alfabeta Soegiyono. (2016). Statistika Untuk Penelitian. Bandung : Alfabeta Tjiptono, F \& Diana, A. (2001). Total Quality Management. Yogyakarta : ANDI

Widjaya, Oey Hannes \& Suryawan, Ian Nurpatria. (2014). Pengaruh Total Quality Management dan Quality Management Information Terhadap Kinerja Perusahaan. Jurnal Media Bisnis Vol. 6 No. 2 